\title{
Seismic Vulnerability Assessment for Steel Structures
}

\section{O. AMELLAL}

Department of Civil Engineering, University Saad Dahled, Blida, Algeria

\section{BENSAIBI}

Department of Materials and Structures, Ecole Nationale Supérieure des Travaux Publics, National School of Built and Ground Works Engineering, Algiers, Algeria

\begin{abstract}
Steel structures are often used in building constructions. However, in seismic area these structures could suffer heavy damages, especially those build according ancient seismic codes. To assess the seismic vulnerability of such structures, studies must be conducted. The aim of the present work is to develop a simple method which gives a state of a studied building according the seismic code in practice. This method is called "Vulnerability index method" and aimed to identify the most important parameters that play a role in the seismic behavior of steel structures. Then weighting factors are determined letting the calculation of a vulnerability index. Then, the studied building is classified according a given classification. Two examples were given to show the efficiency of the method.
\end{abstract}

KEYWORD: Seismic vulnerability; Steel structures; Vulnerability index; Seismic parameters

\section{INTRODUCTION}

Steel structures offer an advantage against the seismic stress due their lightness and ductility These structures can suffer significant damage after an earthquake, [1-2]. The assessment of the seismic vulnerability of steel structures has been the subject of several studies HAZUS, RISK-UE, and RADIUS. Where vulnerability curves have been established using vulnerability index [3-5]. This index is calculated on the assumption of some parameters having an influence on the seismic behaviour of steel constructions and allowing description of seismic quality of such constructions [6].

These methods do not consider all influencing parameters, so in order to improve the existing index and to quantify more accurately the seismic behavior of such structure a vulnerability index method was developed [7-10].

\section{VULNERABILITY INDEX METHOD}

This method considers numbers of structural and non structural parameters that have an influence on the seismic vulnerability of steel structures.

\subsection{Selected Parameters}

These parameters are determined by post-seismic observations from past Algerian earthquakes (Ain Temouchent 1999 and Zemouri 2003) and seismic feedbacks experiences from worldwide. The identified parameters are then:
1- Ductility
2- Bearing capacity
3- Assemblage
4- General maintenance condition
5- Type of soils
8- Plan regularity
9- Modifications
10- Elevation regularity
11- Pounding effect
6- Floor
12- Ground conditions
7- Buckling
13- Roof
14- Details

Among these parameters, Ductility, Bearing capacity and Buckling need calculation, other parameters are related to the in situ observation. In this paper, only Ductility calculation is presented because it is the most important and complex parameter.

\subsection{Ductility}

Under a strong earthquake, the steel frame structures undergo plastic deformations, due to their faculty of energy dissipation. Indeed, they have the ability to resist greater strain than the design one.

To take into account these plastic deformations, the seismic codes consider a reducing factor called "Behavior Factor" defined by the coefficient ' $R$ ' according to the Algerian seismic code (RPA 99 version 2003). The $R$ values are given in the Algerian seismic code. According to this factor a classification given in Table 1, is proposed for steel structures. 
Table 1. Ductility according the behavior factor for steel frame structures.

\begin{tabular}{|l|l|}
\hline Ductility level & Value of "R" \\
\hline High Ductility: Class A & {$[6-4$ [ } \\
\hline Average Ductility: Class B & {$[4-2[$} \\
\hline Low Ductility: Class C & $<2$ \\
\hline
\end{tabular}

\section{QUANTIFICATION OF EACH PARAMETER}

Weighting factors for each parameter are proposed on table II. These factors were deduced from a statistical study based on the seismic feedback experience from past earthquakes in Algeria (Ain Temouchen 1999 and Zemouri 2003). Three classes are considered and a parameter can take only one factor. For each parameter and each category considered, a coefficient (ki) is identified expressing its seismic quality (Table 2).

The "Details" parameter was specified as follows: studwork, dividing walls, balconies, railing, cornices, chimneys, ventilation space, electrical network, gas network, water network and sewage network.

Table 2. Weighting factor "Ki".

\begin{tabular}{|c|l|l|l|l|}
\hline \multirow{2}{*}{$\mathrm{N}$} & \multirow{2}{*}{ Parameters } & \multicolumn{3}{|l|}{ Classes/Ki } \\
\cline { 3 - 5 } & & Class A & Class B & Class C \\
\hline 1 & Ductility & 0.00 & 0.08 & 0.15 \\
\hline 2 & Bearing capacity & 0.02 & 0.07 & 0.09 \\
\hline 3 & Assemblage & 0.02 & 0.06 & 0.15 \\
\hline 4 & $\begin{array}{l}\text { General maintenance } \\
\text { conditions }\end{array}$ & 0.08 & 0.06 & 0.08 \\
\hline 5 & Type of soil & 0.03 & 0.04 & 0.05 \\
\hline 6 & Floor & 0.03 & 0.04 & 0.05 \\
\hline 7 & Buckling & 0.03 & 0.06 & 0.08 \\
\hline 8 & Plan regularity & 0.03 & 0.04 & 0.05 \\
\hline 9 & Modifications & 0.03 & 0.04 & 0.05 \\
\hline 10 & Elevation regularity & 0.03 & 0.04 & 0.05 \\
\hline 11 & Pounding effect & 0.03 & 0.04 & 0.05 \\
\hline 12 & Ground conditions & 0.03 & 0.04 & 0.05 \\
\hline 13 & Roof & 0.03 & 0.04 & 0.05 \\
\hline 14 & Details & 0.03 & 0.04 & 0.05 \\
\hline
\end{tabular}

Three classes are defined for each parameter. Each considered parameter can belong to one of the three defined classes A, B, and C. These classes are declined as follows:

- Class A expresses a parameter inducing a good behaviour of the structure during an earthquake

- Class C, expresses a parameter inducing a bad behaviour of the structure during an earthquake

- Class B expresses an intermediate behaviour of the structure during an earthquake.
Then, the vulnerability index, VI, of a construction is expressed according to the formula (1):

$$
V I=\sum_{i=1}^{14} k_{i}
$$

According to the obtained value for the vulnerability index, three vulnerability classes Green, Orange and Red are proposed, table 3:

Table 3. Vulnerability index classes.

\begin{tabular}{|c|c|c|c|}
\hline Class & Green & Orange & Red \\
\hline VI & {$[0.36-0.54[$} & {$[0.54-0.85[$} & {$[0.85-1]$} \\
\hline
\end{tabular}

The first class associated to the green colour classifies the construction as resistant with no requirement to any repairs.

The second class associated to the orange colour classifies the construction as moderately resistant requiring reinforcement.

The third class associated to the red colour classifies the construction to be a construction with low resistance requiring replacement.

\section{ELABORTED CHART AND DEVELOPED PROGRAM}

In situ observations on structures are important information required to assess the vulnerability of steel frame structures. An investigation chart for a survey was elaborated. The chart contains:

1. General data

2. Geometric characteristics

3. Information on the structural system

4. Information on the ground

5. Details on the non structural

6. General maintenance conditions

Using this information in the elaborated chart we can estimate the coefficient of the different parameters and classify the structures with a program called Vulnerability Index Program "VIP" using Delphi was elaborated providing the vulnerability index values for steel frame structures

\section{APPLICATION}

Several examples have been treated by the developed program. Here in, two case studies are presented as examples.

\subsection{Case study one}

It is a Zinc production manufacture built in 1949 and located in the West part of Algeria. The following figures show the damage undergone by this structure. 


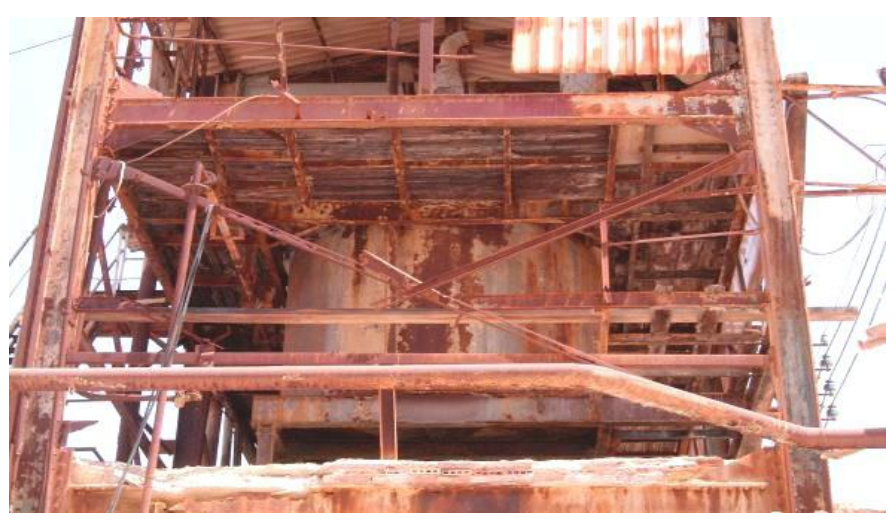

Figure 1. Damage in bracing system.

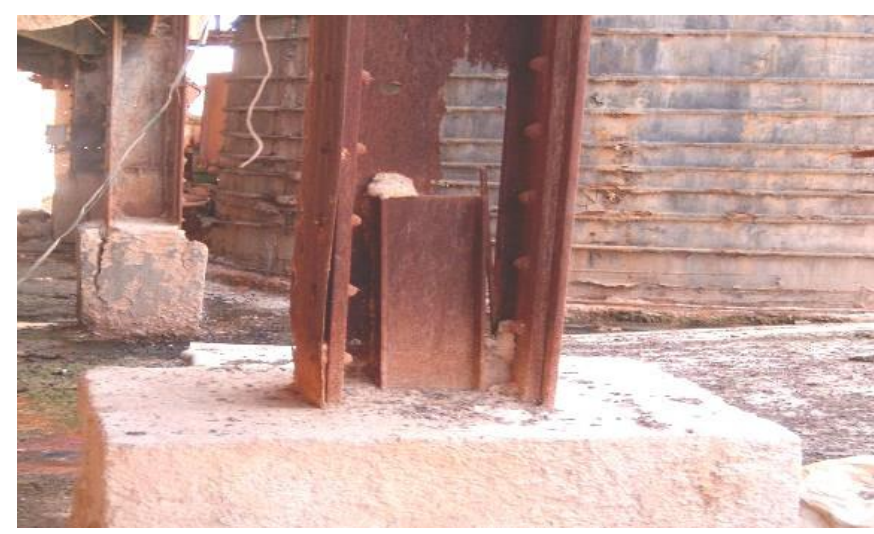

Figure 2. Corrosion of columns.

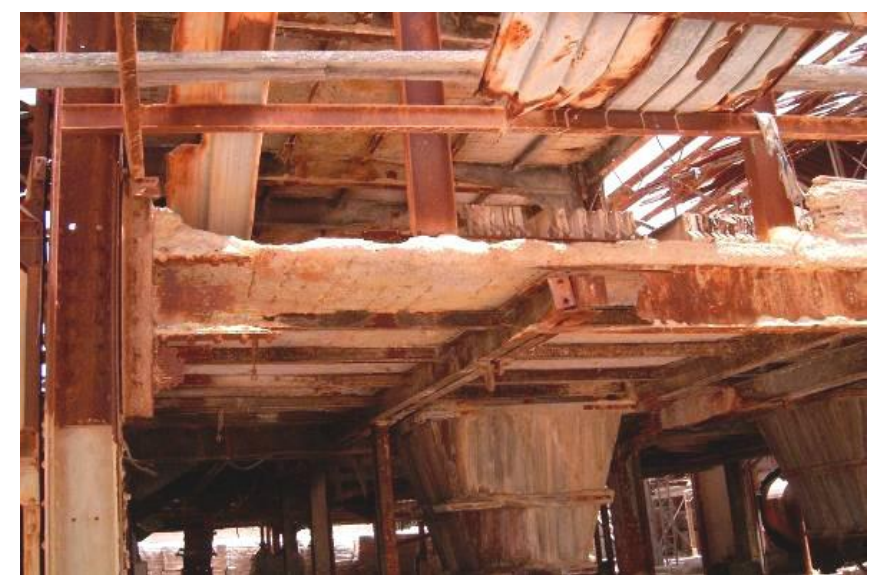

Figure 3. Damage in beams and floors.

The results given by the program are as follow (Table 4).

A vulnerability index of 0.87 was found, this indicates that the structure belong to the red class. The conclusions provided by the Structural Engineering Control (CTC: official organization in charge of control in Algeria) suggest the demolition and the rebuilt of the manufacture according the latest standards.

So, the two conclusions are in adequacy.
Table 4. Manufacture parameters vulnerability.

\begin{tabular}{|c|l|c|c|}
\hline $\mathrm{N}^{\mathrm{o}}$ & Parameters & Class & $\mathrm{Ki}$ \\
\hline 1 & Ductility & $\mathrm{B}$ & 0.08 \\
\hline 2 & Bearing capacity & $\mathrm{C}$ & 0.09 \\
\hline 3 & Assemblage & $\mathrm{C}$ & 0.15 \\
\hline 4 & General maintenance conditions & $\mathrm{C}$ & 0.08 \\
\hline 5 & Type of soil & $\mathrm{B}$ & 0.05 \\
\hline 6 & Floor & $\mathrm{C}$ & 0.05 \\
\hline 7 & Buckling & $\mathrm{C}$ & 0.08 \\
\hline 8 & Plan regularity & $\mathrm{C}$ & 0.05 \\
\hline 9 & Modifications & $\mathrm{A}$ & 0.03 \\
\hline 10 & Elevation regularity & $\mathrm{C}$ & 0.05 \\
\hline 11 & Pounding effect & $\mathrm{B}$ & 0.04 \\
\hline 12 & Ground conditions & $\mathrm{A}$ & 0.03 \\
\hline 13 & Roof & $\mathrm{B}$ & 0.04 \\
\hline 14 & Details & $\mathrm{C}$ & 0.05 \\
\hline
\end{tabular}

\subsection{Case study two}

It is about a manufacture inaugurated in 1975, and composed of four parts: manufacture, storage, maintenance and administration. It should be noted that the process of manufacturing zinc liberates $\mathrm{H}_{2} \mathrm{SO}_{4}$ which is very harmful to the metal, as it accelerates the corrosion process. This manufacture built near the sea on sandy soils and limited to the south by a high cliff. Photos below were taken on site during our visit.

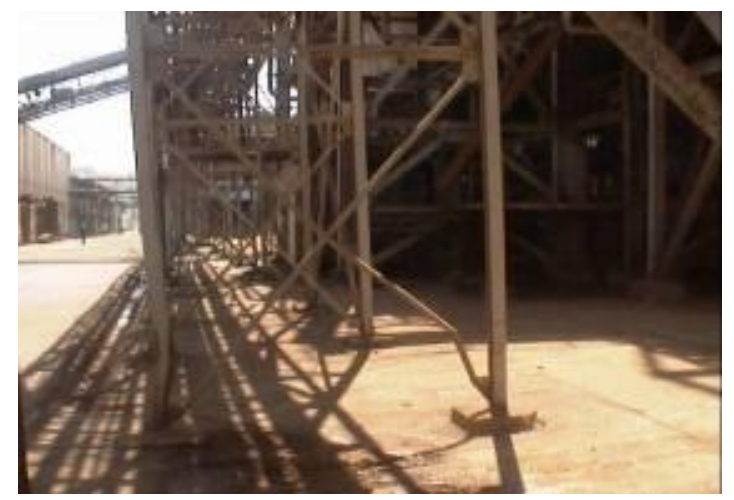

Figure 4. Deformation of bracing system and buckling column.

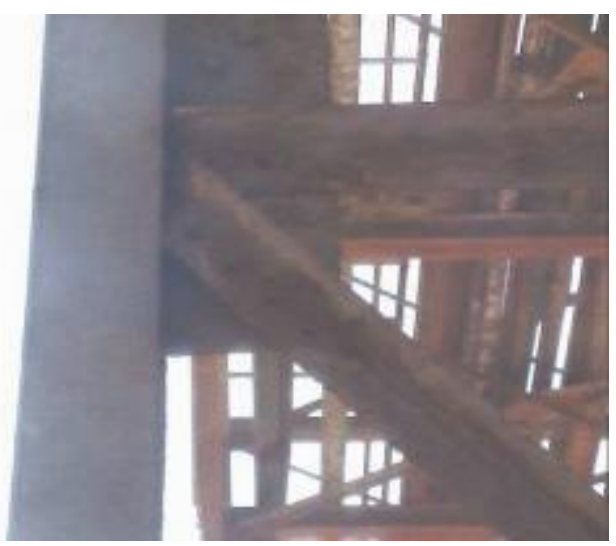

Figure 5. Lack of bolts in the assembly system. 


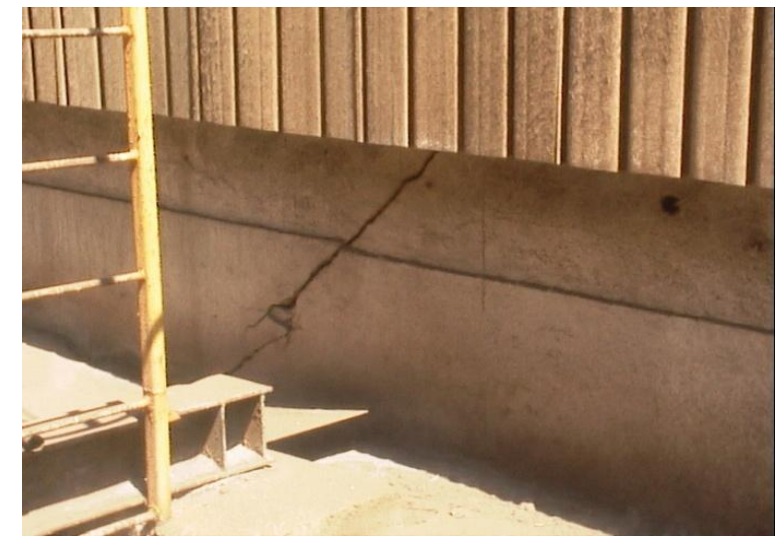

Figure 6. Cracking 45 degrees to both directions and both side of joint.

The VIP gives the following results

Table 4. Result of the application of the Zinc manufacture.

\begin{tabular}{|c|l|c|c|}
\hline $\mathrm{N}^{\mathrm{o}}$ & Parameters & Class & $\mathrm{Ki}$ \\
\hline 1 & Ductility & $\mathrm{B}$ & 0.08 \\
\hline 2 & Bearing capacity & $\mathrm{B}$ & 0.07 \\
\hline 3 & Assemblage & $\mathrm{B}$ & 0.08 \\
\hline 4 & General maintenance conditions & $\mathrm{B}$ & 0.06 \\
\hline 5 & Type of soil & $\mathrm{C}$ & 0.05 \\
\hline 6 & Floor & $\mathrm{B}$ & 0.04 \\
\hline 7 & Buckling & $\mathrm{B}$ & 0.06 \\
\hline 8 & Plan regularity & $\mathrm{C}$ & 0.05 \\
\hline 9 & Modifications & $\mathrm{A}$ & 0.03 \\
\hline 10 & Elevation regularity & $\mathrm{C}$ & 0.05 \\
\hline 11 & Pounding effect & $\mathrm{C}$ & 0.05 \\
\hline 12 & Ground conditions & $\mathrm{C}$ & 0.05 \\
\hline 13 & Roof & $\mathrm{B}$ & 0.04 \\
\hline 14 & Details & $\mathrm{C}$ & 0.05 \\
\hline
\end{tabular}

The program gives $\mathrm{VI}=0.76$, so the structure is classified Orange. This appears in concordance with observations made during our site visit.

\section{CONCLUSION}

A vulnerability index method for steel structure has been developed and presented in this study. Elaborated specially for steel structures, it gives reasonable results regarding the influence of the different parameters such as Ductility, Bearing capacity and Buckling on the seismic behaviour of steel structure.

A classification has been established; the results from this classification are in accordance with the one done in situ. As a result, this classification can be used by engineers to reduce seismic risk and casualties in case of an earthquake.

\section{REFERENCES}

[1] Jerez Barbosa, R. S "Seismic vulnerability of buildings: Response and damage assessment," Ph.D thesis, university Paris-est, Paris, France, march, 2011.

[2] C.G.S., Règles parasismiques Algériennes RPA 99 V. 2003, Algéria, 2003.

[3] CNERIB, Règles de Conception et de Calcul des Structures en acier CCM 97, Algérie, 1997.

[4] Davidovici, V., "Construction en Zone Sismique," Publisher the Moniteur. Paris, France, 1999.

[5] Nollet, M.J. "Evaluation de la Vulnérabilité Sismique des Bâtiments Existant," cahier technique de l'ETS, Ecole de Technologie Supérieure Université du Québec, Montréal, Canada, 2004.

[6] RISK-UE., An advanced approach to earthquake risks scenarios with applications to differente European towns, WP4 : Vulnerability of current building, EVK4-CT-200000014, 2003.

[7] National Institute of Building Sciences, "Hazards risk assessment program," USA, 1997.OYO Corporation, RADIUS methodology, IDNDR, (1999).

[8] Akkase, M. N, Thaughts on Concepts of Seismic Hazards, Vulnérability and seismic Risk, 9th European confer on Earthequake engineering Vol X. 2006.

[9] Marano, G .C., Greco, R. Morrone. E" Analytical evaluation of essential facilities fragility curves by using a stochastic approach "Original Research Article Engineering Structures. Vol 33, Issue 1, Jan 2011.

[10] Belheouane, F. I. Bensaibi, M. "Evaluation of the vulnerability index for reinforced concrete construction in Algeria undo seismic action," AES Technical review, part C, IJATMA, vol 1, January 2012, pp. 101-106. Jan 2012.

[11] Yakut, A.,Altuğ Erberik, M., Sucuoğlu, H., \& S. Akka "Rapid Seismic Assessment Procedures for the Turkish Building Stock, " Geotechnical, Geological and Earthquake Engineering. Volume 26, pp 15-35, 2014.

[12] Ghasemi Azadkhani, M. J., Ahmadi Disfani, Y., \& Reza Tavassoli, M. "Evaluating Earthquake Disaster Management in the Worn Urban," Journal of Civil Engineering and Urbanism, Vol 4, Issue 1: 41-46, ISSN2252-0430, 2014.

[13] Gueguen, P. Lagomarismo, S. \& Cattari, S "Seismic Vulnerability of structures," published in Great Britain and the United States, 2013.

[14] Mebarki, A., Boukri, M., Laribi, A., Farsi, M. "Seismic vulnerability: theory and application to Algerian buildings" Journal of seismology, ISSN 1573-157X, vol. 18, no2, pp. 331-343, 2014. 